\title{
ETERNO RETORNO E A PERFEIÇÃO INSTITUCIONAL EM MAQUIAVEL
}

\section{Ricardo Manoel Oliveira Morais ${ }^{1}$ \\ Adriana Campos Silva ${ }^{2}$}

\section{Resumo}

O objetivo do texto é analisar o eterno retorno político e a possibilidade de evitá-lo pelo arranjo institucional republicano em Maquiavel. Neste sentido, este trabalho, realizado por meio de uma análise bibliográfica das obras maquiavelianas, situa-se no campo da Filosofia Política, sobretudo quando se assume que a questão central desta área do saber é a pergunta pelo melhor regime. Para Maquiavel, a história humana, que é política (pois o ser humano é um ser político), é cíclica e é marcada pela degenerescência natural das formas puras de governo (principado, aristocracia, democracia), o que leva ao eterno retorno. Todavia, o caráter cíclico do político é relativo, já que uma cidade bem ordenada pode suspender a degenerescência político-institucional, como Roma. Ou seja, o resultado político alcançado pela república romana deve ser compreendido como paradigmático.

Palavras-chave: perfeição institucional; eterno retorno; formas de governo; República.

\section{INTRODUÇÃO}

Este artigo tem por objetivo compreender a possibilidade de suspensão do eterno retorno políticotemporal por meio de um arranjo institucional republicano misto, a partir de algumas das reflexões presentes na obra Discursos sobre a primeira década de Tito Lívio, de Maquiavel. Conforme será examinado, existiriam três formas "puras" de governo - o principado, a aristocracia e o governo popular (democracia) -, às quais

\footnotetext{
${ }^{1}$ Doutor em Direito pela UFMG. Mestre em Filosofia pela UFMG. Graduado em Direito (FDMC) e em Filosofia (FAJE). E-mail: ricardo_mom@hotmail.com

${ }^{2}$ Doutora em Direito pela Universidade Federal de Minas Gerais (2002).E-mail: adrilaw@hotmail.com
} 
correspondem as três formas degeneradas - tirania, oligarquia e licença - e qualquer comunidade política se organizaria como uma delas. $\mathrm{O}$ elemento que irá determinar a forma de governo de uma cidade é o conflito entre dois humores, o dos grandes e o da plebe, o que também será desenvolvido.

Existe uma instabilidade que marca cada uma das formas puras de governo, fazendo com que elas rapidamente se corrompam e se transformem no modelo de governo seguinte, isto é, uma comunidade organizada como principado tende a se transformar em tirania, de modo que aqueles que estão próximos ao príncipe tendem a insurgir contra ele e a tomar o poder, instituindo uma aristocracia. Esta, por sua vez, tende a se transformar numa oligarquia, fazendo com que o povo tome o poder e institua um governo popular que, igualmente, se transformará numa licença. Nesta, só se pode evitar a total desconstituição da polis se se recorrer a um governante único, capaz de reordenar a cidade, o que levaria ao retorno de um principado. O que se intenta sustentar é que mesmo que Maquiavel aponte para uma adesão ao esquema cíclico polibiano, sua concordância não é irrestrita. Isso porque, conforme também será examinado, uma comunidade política pode combinar as três formas de governo em um regime misto de modo que uma estabilize a outra, evitando que as instituições se corrompam e haja o eterno retorno. A durabilidade de um modelo de governo misto depende do modo pelo qual os humores travam os seus conflitos.

Assim, primeiramente será examinada, brevemente, a questão dos humores, na medida em que a relação entre eles é um dos principais determinantes institucionais de uma comunidade política. Esta relação, como demonstra o florentino, é necessariamente conflituosa. O que irá determinar se uma cidade é bem ordenada ou não são os efeitos gerados pelos conflitos. Neste sentido, conflito entre os grandes e o povo pode originar qualquer uma das três formas de governo, bem como que é uma relação de instabilidade entre os humores que leva à degeneração cíclica de uma comunidade política. A passagem de uma tirania para um governo de poucos pode ser entendida como a sobreposição de humor dos grandes, ao passo que a instituição de um governo popular após a derrocada de uma oligarquia pode ser compreendida como a sobreposição de humor do povo. Aqui pretende-se examinar, também, o papel que a história desempenha das reflexões de Maquiavel. Isso porque sua obra é marcada por incursões histórias, a partir das quais ele apresenta a sua teoria (dentre as quais a questão dos conflitos entre os humores).

Em um segundo momento, será analisada a abordagem maquiaveliana do caráter cíclico da história, onde será marcada a importância de uma fundação e de um corpo institucional voltados para a manutenção do ethos da liberdade, uma vez que apenas um regime livre (republicano) é capaz de suspender a tragicidade do eterno retorno, como foi o caso de Roma. Isso porque apenas um regime que se funda na liberdade e se estrutura de forma mista é capaz de evitar a corrupção natural das formas puras de governo. Ainda, será analisado o sucesso de Roma em suspender o ciclo de corrupção por meio de um arranjo político que deu espaço de participação aos 
dois humores ao instituir um sistema onde coexistiram principado (cônsules), aristocracia (senado) e democracia (tribunos). Roma, mesmo tendo passado por parte do ciclo político (foi um principado que se transformou em tirania; de tirania passou a aristocracia; de aristocracia, passou a oligarquia), foi capaz de evitar se recolocar no rumo da grandeza transformar o seu regime oligárquico em uma república popular, alcançando o que se poderia classificar como perfeição institucional.

Um elemento ao qual vale a pena chamar a atenção, o que será feito na última parte do artigo, é o fato de que Maquiavel é um dos responsáveis por promover uma ruptura com a tradição que o antecedeu, não apenas por posicionar a República de Roma como o maior de todos os impérios já existentes, como por colocar o conflito (e não a harmonia) como o principal motor da vida política. Noutros termos, quando Maquiavel pensa o conflito como propulsor da política, ele se destaca da tradição que o precedeu. Assim, nas considerações finais, será chamada a atenção para o fato de o conflito ser, no pensamento de Maquiavel, uma categoria ontológica da política.

\section{OS HUMORES E A QUESTÃO A HISTÓRIA}

Antes de se tratar da questão do eterno retorno propriamente, é necessário situar a questão dos humores políticos fundamentais bem como a forma como Maquiavel concebe a história, uma vez que o ciclo de degeneração e a perfeição institucional estão diretamente relacionados com a forma como os humores se relacionam em uma comunidade política, além do que, Maquiavel tem uma obra marcada por análises e incursões históricas.

A questão dos humores é, na obra de Maquiavel e na tradição política, bastante complexa. Esta problemática, embora ausente nos escritos de chancelaria, aparece de forma recorrente n’ O Príncipe (capítulos IX e XIX), nos Discursos sobre a primeira década de Tito Lívio (Livro I) e na História de Florença (Livros II e III). Existem basicamente dois eixos interpretativos para se entender os humores (umori) em Maquiavel: analisa-los em termos de motivação de classe, mas que vão além de uma compreensão estática da oposição entre oprimidos e opressores; interpretá-los a partir a influência da teoria médica e fisiológica antiga em seu pensamento. As duas abordagens "[...] não são necessariamente incompatíveis: [uma] privilegia as supostas origens cosmológicas dos apetites que separam segmentos da sociedade, ao passo que [a outra] privilegia os efeitos reais desses apetites, a saber, desigualdades de riqueza e de poder político" (MCCORMICK, 2013, p.255). Neste artigo as duas abordagens não serão trazidas em separado ${ }^{3}$.

\footnotetext{
${ }^{3}$ Gaille-Nikodimov, em Conflit civil et liberté. La politique machievélienne entre histoire et médecine, mostra a influência da teoria médica no pensamento maquiaveliano sobre a relação entre os humores e o equilíbrio do corpo social. o emprego de termos
} 
Para Maquiavel, em toda comunidade política existem dois humores antagônicos, o dos grandie o da plebe, que se enfrentam e dão origem a alguma das formas "puras" de governo ou a um modelo misto e fértil para a liberdade e a virtù $\dot{u}^{4}$ A natureza do desejo dos grandi é sempre positiva e determinada, na medida em que quer oprimir e aumentar a sua dominação, ao passo que o do povo é indeterminado e negativo, agindo sempre de modo a não ser oprimido (ADVERSE, 2007). Estas forças antagônicas constituem a dinâmica fundamental de toda e qualquer comunidade política (polis) constituída. Conforme explica Gaille Nikodimov (GAILLE NIKODIMOV, 2004, p.33), o conceito de humor (umore ou omore) é uma noção chave para compreender as condições de possibilidade para o surgimento e a manutenção de um regime livre. Em outras palavras, os humores antagônicos são o determinante institucional, pois as leis favoráveis à ampliação institucional e à manutenção da liberdade na república romana advieram da desunião conflituosa entre os grandes e o povo, conforme será examinado.

Vale também pontuar que quando Maquiavel analisa a questão dos humores, dos conflitos entre eles e dos desdobramentos institucionais disso, ele o faz por meio de análises históricas. O florentino, já na introdução ao Livro I dos Discursos sobre a primeira década de Tito Lívio, sugere um reexame crítico do passado. Para ele, dos litígios civis do passado e das leis e instituições que foram capazes de ordená-los (e não os resolver de modo absoluto) deve-se, mais do que simplesmente se admirar, aprender algo para aperfeiçoar as instituições do presente (VALVERDE, 1999). Entretanto, as análises maquiavelianas parecem incorrer numa contradição: por um lado, o florentino, na dedicatória da História de Florença, se opõe às histórias que não se preocupam com a verdade dos fatos; por outro, suas investigações histórico-político-institucionais vão além de um mero relato do passado, pois ele apresenta sua teoria a partir dele e com uma escrita permeada de artifícios retóricos.

Embora Maquiavel fosse familiarizado com os relatos históricos antigos, seu exame, mais que uma preocupação com o mapeamento exato do passado, deve ser compreendido como uma combinação entre (1) aquilo que ele considerava como a melhor república possível no real, (2) uma consideração sobre quais arranjos

médicos no pensamento político é algo recorrente na história do pensamento desde os pré-socráticos. Todavia, o pensamento humoral não é unívoco na história do pensamento humano, nem é transmitido de forma sistemática desde que foi formulado na antiguidade. Embora o objetivo deste estudo, ao recorrer à teoria dos humores de Maquiavel, seja analisar a forma como as castas sociais se enfrentam e seus efeitos institucionais, essa reflexão pode ajudar a elucidar o caráter ambíguo com que Maquiavel trata da questão do conflito em seus escritos, bem como a necessidade de haver equilíbrio no corpo social, apesar de os enfrentamentos serem essenciais para uma vida republicana saudável.

${ }^{4}$ A partir de uma analogia com os humores médicos, podem-se examinar alguns elementos da obra de Maquiavel: 1) a correlação entre saúde e liberdade, bem como o fato de que tanto as leis favoráveis à liberdade/saúde da cidade - Discursos, Livro I, capítulo 4 - quanto todos os males/doenças - História, Livro III, capítulo 1 - nascem da desunião entre os humores, isto é, os humores são tanto a causa da saúde (liberdade) quanto da doença (corrupção e rompimento do corpo social); 2) o fato de que os humores do corpo social, assim como os do corpo humano, são potencialmente nocivos e desequilibrados (irrefreados; desmesurados) se considerados de forma isolada; 3 ) o fato de que nenhum humor pode ser considerado como "vazio" de conteúdo; 4) o fato de que remédios podem ser repetidos, uma vez que os humores não se alteram em substância no transcorrer do tempo (noção de imitação) (ponto que será desenvolvido no próximo item) 
poderiam aperfeiçoar e atualizar esse modelo e (3) uma aprofundada análise de como estes elementos existiram no passado e a possibilidade de eles serem imitados ou representados no presente. Assim, se Políbio enfatizava o equilíbrio entre as forças sociais e políticas em Roma e Lívio sugeria que o senado romano, por vezes, manipulava o povo em prol de interesses da nobreza, assim como a história moderna assinala fortes elementos oligárquicos na república de Roma, a análise maquiaveliana vai além.

Como uma fusão do que é (ou era) e do que deve ser, o republicanismo de Maquiavel não deve ser visto como uma mera recapitulação de fontes clássicas, ou como uma história mal traçada, ou ainda como um exercício inteiramente metafórico. Desafiando um imperativo mais recente das ciências sociais, no sentido de distinguir os aspectos descritivos dos aspectos normativos em uma análise - imperativo cuja origem é frequentemente creditada a Maquiavel -, os Discursos entrelaçam ambos de modo geralmente sugestivo, mas muitas vezes analiticamente frustrantes (MCCORMICK, 2013, p.258).

Ames (2004, p.103) esclarece que Maquiavel estava determinado a estabelecer regras gerais para a ação política, compreendendo a história como uma obra política, como um encadeamento de ações e seus resultados (necessários e contingentes). Mesmo que Maquiavel tivesse consciência de que não se pode conhecer a verdade sobre as coisas antigas, isso não significa que se deve deixa-las de lado. Suas leituras históricas foram dirigidas "[...] pela preocupação de evidenciar os exemplos que corroboravam as regras e máximas que orientavam a ação política. A compreensão dessas regras ampliava o conhecimento dos meios [...] aumentando as chances de êxito e reduzindo o risco do fracasso" (AMES, 2004, p.103).

Vale frisar que Maquiavel, além de ter uma obra marcada por análises e incursões históricas, concebia a história em termos cíclicos, demonstrando suas teorias a partir da compreensão do passado. Isso porque, conforme se pode depreender do caráter ontológico no que tange à presença dos humores em toda e qualquer comunidade política, embora hajam algumas contingências, a presença dos humores é uma constância, razão pela qual a história não é uma sucessão de fatos desconexos. Havia, para Maquiavel, uma potencialidade de o eterno retorno se instaurar numa perspectiva trágica, na medida em que o ciclo histórico pressupõe a corrupção eterna das instituições políticas e dos cidadãos caso os conflitos entre os humores não levem a um regime misto. A única possibilidade de se suspender a tragicidade cíclica seria por meio de uma fundação livre ou uma refundação das instituições tendo como telos a liberdade, refundação esta que pode ser tanto por força de acidentes e contingências históricas, como foi o caso de Roma, quanto por um legislador virtuoso que irá reformar as instituições.

O florentino, já na introdução ao Livro I dos Discursos sobre a primeira década de Tito Lívio, sugere um reexame do passado (exercício recorrente nos renascentistas), mas de modo crítico. Para ele, dos litígios civis do passado e das leis e instituições que foram capazes de ordená-los (e não os resolver de modo absoluto) deve-se, mais do que simplesmente se admirar, aprender algo para aperfeiçoar as instituições do presente (VALVERDE, 
1999). Com isso, as análises históricas maquiavelianas parecem incorrer numa contradição: por um lado, o florentino, na dedicatória da História de Florença, se opõe às histórias que não se preocupam com a verdade dos fatos; por outro, suas investigações político-institucionais vão além de um mero relato do passado, pois ele apresenta sua teoria a partir da história e com uma escrita permeada de artifícios retóricos.

Entretanto, segundo McCormick (2013), a visão apresentada pelo florentino é diferente tanto daquelas presentes em suas fontes, que eram os historiadores antigos, quanto de grande parte da pesquisa histórica contemporânea, embora contenha pontos de convergência com ambas, como aponta Bignotto:

Maquiavel tinha tido predecessores ilustres, que deixaram obras importantes, que the serviriam de fonte e inspiração. Devemos destacar pelo menos dois historiadores e humanistas florentinos que influenciaram nosso autor e ao mesmo tempo fugiram do padrão historiográfico corrente: Leonardo Bruni (1370-1444) e Poggio Bracciolini (13801459). Bruni, sobretudo, escreveu uma história de Florença que ultrapassava os limites da história educativa, ligando intimamente suas preocupações teóricas com a narração dos acontecimentos mais importantes de sua cidade e que já haviam servido de fio condutor para os cronistas florentinos do trecento [...]. Bruni introduziu um conceito essencial para a compreensão da história florentina: o conceito de liberdade. Para ele, compreender a formação e o desenvolvimento de sua cidade era compreender a relação que os diversos acontecimentos tinham com a liberdade e com as instituições que a representavam (BIGNOTTO, 1996, p.185-186).

Embora Maquiavel fosse familiarizado com os relatos históricos antigos, seu exame, mais que uma preocupação com o mapeamento exato do passado, deve ser compreendido como uma combinação entre (1) aquilo que ele considerava como a melhor república possível no real, (2) uma consideração sobre quais arranjos poderiam aperfeiçoar constantemente esse modelo e (3) uma aprofundada análise de como estes elementos existiram no passado e a possibilidade de eles serem imitados ou representados no presente. Assim, se Políbio enfatizava o equilíbrio entre as forças sociais e políticas em Roma e Lívio sugeria que o Senado romano, por vezes, manipulava o povo em prol de interesses da nobreza, assim como a história moderna assinala fortes elementos oligárquicos na república de Roma, a análise maquiaveliana vai além.

Como uma fusão do que é (ou era) e do que deve ser, o republicanismo de Maquiavel não deve ser visto como uma mera recapitulação de fontes clássicas, ou como uma história mal traçada, ou ainda como um exercício inteiramente metafórico. Desafiando um imperativo mais recente das ciências sociais, no sentido de distinguir os aspectos descritivos dos aspectos normativos em uma análise - imperativo cuja origem é frequentemente creditada a Maquiavel -, os Discursos entrelaçam ambos de modo geralmente sugestivo, mas muitas vezes analiticamente frustrantes (MCCORMICK, 2013, p.258).

Ames, em "História e ação política em Maquiavel", esclarece que Maquiavel estava determinado a estabelecer regras gerais para a ação política, compreendendo a história como uma obra política, como um encadeamento de ações e seus resultados. Mesmo que o florentino tivesse consciência de que não se pode conhecer a verdade sobre as coisas antigas, isso não significa que se devem deixá-las de lado. A leitura histórica maquiaveliana "[...] foi dirigida pela preocupação de evidenciar os exemplos que corroboravam as regras e 
máximas que orientavam a ação política. A compreensão dessas regras ampliava o conhecimento dos meios [...] aumentando as chances de êxito e reduzindo o risco do fracasso" (AMES, 2004, p.103).

Embora muitos atores políticos de sua época ignorassem os ensinamentos da história, para Maquiavel, essa era uma das causas de eles não conseguirem alcançar a grandeza e a glória como os antigos. Se, para o secretário florentino, o conhecimento histórico desinteressado dos fatos não era relevante, sua análise de Roma não tem o objetivo de ser um mero esclarecimento erudito, mas de mostrar como os conflitos viabilizaram a grandiosidade daquela república, examinando os seus efeitos positivos, como em Roma, e negativos, como em Florença, tentando compreender formas de tornar possíveis os primeiros.

Portanto, pode-se constatar um importante elemento de originalidade de Maquiavel em relação à historiografia humanista. Grande parte dos historiadores que o precederam, sobretudo os do quattrocento, tinham a preocupação de apenas descobrir a origem das cidades e estabelecer um nexo de causalidade entre a forma constitucional primeira e a história posterior, sem problematizar as potencialidades de tais ordenações se corromperem. Maquiavel, por outro lado, estava preocupado em compreender o passado para resolver os problemas do presente, sendo o principal deles a instituição de um regime virtuoso, capaz de suspender o ciclo de corrupção (BIGNOTTO, 1996, p.188). Vale dizer que embora muitos atores políticos de sua época ignorassem os ensinamentos da história, para Maquiavel essa era uma das causas de eles não conseguirem alcançar a grandeza e a glória como os antigos. Se para o secretário florentino o conhecimento histórico desinteressado dos fatos não era relevante, sua análise de Roma não tem o objetivo de ser um mero esclarecimento erudito, mas de mostrar como os conflitos viabilizaram a grandiosidade daquela república.

\section{OS CICLOS DE DEGENERAÇÃO POLÍTICA}

Maquiavel, nos Discursos sobre a primeira década de Tito Lívio, analisa a história da república de Roma, tomando-a como modelo paradigmático na medida em que Roma foi capaz de não apenas evitar a tragédia do eterno retorno, mas de alcançar a grandeza e a glória devido à virtude de seus cidadãos e à perfeição institucional (o que se deveu à institucionalização da liberdade). No início da obra, Maquiavel tenta dissuadir seus leitores da possibilidade de se utilizar da força principesca para resolver de uma vez os dilemas e "eternos" conflitos da política, pois eles são intrínsecos à realidade. Assim, contrariamente à tradição, Maquiavel vincula liberdade à discórdia, examinando como os conflitos influenciaram no surgimento de instituições políticas livres, pois "[...] todas as leis para a liberdade nascem da 'desunião’ entre aristocracia e povo” (MARIN, 2007, p.12). O florentino afirma abertamente que os conflitos políticos foram responsáveis pela grandeza da república romana.

Para chegar às causas que geraram a liberdade e a perfeição institucional romana, Maquiavel diferencia 
historicamente o nascimento das cidades em geral do de Roma. Se Roma é o exemplo paradigmático da perfeição institucional e se esta perfeição decorria dos conflitos e da institucionalização da liberdade (o que viabilizou a suspensão do eterno retorno), que foram responsáveis pela grandeza romana, é premente diferenciar a história do surgimento e da ordenação desta república "perfeita" das demais cidades (repúblicas fracas e principados deficientes) para que se tente, no presente, traçar um rol de ações baseadas no passado visando a grandiosidade.

Sendo a fundação livre essencial para a grandiosidade (embora não seja o único determinante) e para se estabelecer as bases da liberdade e das boas ordenações, Maquiavel problematiza nos primeiros capítulos $(1,2$, 3 e 10) os vários tipos de fundação das cidades para, em seguida, diferenciá-los do tipo da fundação romana Roma. Ele "esquematiza" seu exame sobre a fundação de uma polis da seguinte forma: 1) as cidades que foram fundadas por habitantes nativos daquela localidade (Atenas e Veneza); 2) as cidades que foram fundadas por forasteiros. Dentre as cidades que foram fundadas por forasteiros, há aquelas que: 2.1) nascem submetidas a outras e dificilmente progridem ou realizam grandes feitos; 2.2) têm uma fundação livre de qualquer submissão. Dentre as cidades que têm uma fundação livre, há aquelas que: 2.2.1) são ordenadas de uma só vez por um edificador virtuoso; 2.2.2) não tendo sido edificadas por um fundador sábio e virtuoso, perfazem o ciclo polibiano de degeneração política ou caem na dominação de estrageiros; 2.2.3) não tendo sido edificadas por um fundador sábio e virtuoso, são capazes de alcançar a boa ordenação por acontecimentos e contingências, suspendendo o eterno retorno da degenerescência política, como foi o caso de Roma.

Quando uma cidade é fundada por habitantes nativos (1), tal fundação decorre da percepção dos habitantes de que eles, individualmente, dificilmente podem se defender de ameaças concretas e em potencial, razão pela qual devem se agrupar em torno de alguém escolhido por eles. Assim, eles escolhem um local e se reúnem para viverem juntos. "No segundo caso [(2)], as cidades edificadas por forasteiros ou o são por homens livres [(2.2)], ou que dependem de outrem [(2.1)]: é o que ocorre com as colônias mandadas por repúblicas ou por príncipes para aliviarem suas cidades de habitantes, ou para defenderem as terras recém-conquistadas [...]”. As cidades que nascem submetidas a outras (2.1), por não serem livres, dificilmente realizarão grandes progressos. Por outro lado, há as cidades que, fundadas por forasteiros, têm um início marcado pela virtù de edificadores livres (2.2), podendo alçar a grandiosidade. "São livres os edificadores de uma cidade quando alguns povos, quer sob o comando de um príncipe, quer por si mesmos, são obrigados a abandonar a terra natal e a buscar novos locais, seja por doença, por fome ou por guerra [...]” (MAQUIAVEL, 2007, p.9).

A importância que Maquiavel atribui à liberdade é tamanha que, no capítulo 2, ele deixa de lado a análise das cidades que nasceram submetidas a outras, visto que elas não tendem a realizar grandes progressos. As cidades que são fundadas com liberdade têm o potencial de se expandir, pois possuem, em potência, a força de alçar a grandeza e a glória. "[...] o começo é mais que metade do todo, o fator liberdade cívica é fundamental, por 
uma vez amealhado na fundação magnífica de uma cidade, é o aval quase completo da conservação do mesmo no processo de expansão da cidade" (VALVERDE, 1999, p.338). Dentre as cidades que nascem livres, "[...] algumas receberam leis, em seu princípio ou depois de não muito tempo, de um só homem e de uma só vez [(2.2.1)] e outras as receberam ao acaso e em várias vezes [(2.2.2) e (2.2.3)], segundo os acontecimentos, como ocorreu com Roma” (MAQUIAVEL, 2007, p.13).

A partir daí, Maquiavel passa à análise da fundação de Roma ao mesmo tempo em que expõe a concepção dos ciclos históricos de Políbio e, mesmo sem citá-lo (VALVERDE, 1999), descreve as formas de governo pelas quais Roma passou e a série de acontecimentos que a levou à perfeição. O florentino lembra que existem três espécies de governo: o monárquico, o aristocrático e o popular. Qualquer um que intente ordenar uma cidade deverá escolher dentre elas a ordem que melhor convém aos seus objetivos.

[...] para discorrer sobre as ordenaçôes da cidade de Roma e os acontecimentos que a levaram à perfeição, direi o que dizem alguns que escreveram sobre as repúblicas, ou seja, que há nelas um dos três estados, chamados principado, optimates e popular; e que aqueles que ordenam uma cidade devem voltar-se para um deles, segundo o que lhes pareça mais apropriado. Outros - os mais sábios, segundo a opinião de muitos - são de opinião que existem seis formas [ragioni] de governo, das quais três são péssimas e três são boas em si mesmas, mas são fáceis de corromper-se, que também elas vêm a ser perniciosas. Os bons são os três acima citados; os ruins são outros três que desses três decorrem; e cada um destes se assemelha àquele que the está próximo, e facilmente passam de um a outro: porque o principado facilmente se torna tirânico; os optimates com facilidade se tornam um governo de poucos; o popular sem dificuldade se torna licencioso. De tal modo que, se um ordenador de república ordena um desses três estados numa cidade, o ordena por pouco tempo, pois nada poderá impedir que resvale para o seu contrário, pela semelhança que têm neste caso a virtude [virtute] e o vício (MAQUIAVEL, 2007, p.14).

As variações cíclicas entre as formas de governos nascem quando os homens se organizam em comunidade. Se, em princípio, os homens vivem dispersos, como animais, posteriormente, eles passam a se grupar para se defender melhor, fazendo do mais forte o seu príncipe, devido ao respeito pela sua força ou coragem. É criada, assim, uma concepção de bom e honesto em relação ao que é pernicioso, "[...] porque, vendo eles que se alguém prejudicava seu benfeitor isso suscitava ódio e compaixão entre os homens, censurando-se os ingratos e homenageando-se os gratos [...]: daí proveio o conhecimento da justiça” (MAQUIAVEL, 2007, p.15).

Todavia, este principado inicial rapidamente se degenera, pois, os príncipes começam a se fazer por sucessão, não mais por escolha. São deixadas de lado as obras virtuosas e os príncipes, sob a crença de que devem sobrepujar os outros em suntuosidade, passam a ser odiados por todos os que ele submete. Temendo a dimensão deste ódio, os príncipes passam do temor ao ataque, nascendo a tirania, que faz surgir conspirações e conjurações contra eles. Assim, aqueles que por generosidade, grandeza ou nobreza, conseguem mobilizar as multidões e derrubar o príncipe passam a ser obedecidos pelo povo, que os vê como seus libertadores. Estes, rejeitando a possibilidade do governo um, formam um governo de poucos. 
Tal governo, lembrando da recente tirania, é dirigido de forma virtuosa segundo as boas leis instituídas, abrindo mão das comodidades em prol da utilidade comum. Pode-se dizer que o governo da coisa pública é, inicialmente, diligente e probo. Todavia, quando a administração passa aos filhos destes optimates, que não conheceram as variações da fortuna e não se preocupam em promover a igualdade civil, o governo dos poucos se corrompe, tendendo à ganância e à ambição. Tão logo este regime se torna oligárquico, não respeitando a civilidade [civilta] ], ocorre com ele o que ocorreu ao tirano: a derrocada por uma multidão insatisfeita. Esta, tendo viva a memória do tirano e a de uma oligarquia, se constitui como um governo popular, ordenado de modo que não seja dada autoridade aos poucos e a um só.

Neste ponto do ciclo existe estabilidade, assim como em todas as organizações políticas novas, o que não perdura. Com o passar das gerações e o fim daquela geração que ordenou o governo popular, chega-se progressivamente à licença. Assim, " coagidos pela necessidade ou pela sugestão de algum homem bom, para fugirem de tal licença, voltam de novo ao principado; e deste, gradativamente, se retorna para a licença, de modo e pelas razões já ditas" (MAQUIAVEL, 2007, p.16-17).

Necessário frisar que a adesão de Maquiavel à concepção cíclica (que remete a Políbio) não é irrestrita. Ames, em "História e Ação Potítica em Maquiavel”, e Bignotto (1991) ressaltam que o eterno retorno - categoria absoluta no pensamento antigo - não é assumido como tal pelo florentino. "Se Maquiavel diz que o tempo é cíclico, também não deixa de nuançar de tal forma essa afirmação, que terminamos por achar que a ciclicidade do tempo é apenas um paradigma abstrato, capaz de apontar uma tendência, mas não de desvelar o real" (BIGNOTTO, 1991, p.176). Tanto a tendência cíclica não é absoluta que o próprio Maquiavel expõe as ressalvas a ela.

A primeira delas é que uma cidade dificilmente pode passar muitas vezes por estes ciclos e permanecer sólida. "Muitas vezes ocorre que, passando uma república por tais revezes e faltando-lhe sempre discernimento e forças, acaba ela por se tornar súdita de algum estado próximo que seja mais bem-ordenado que ela [...]” (MAQUIAVEL, 2007, p.17). A segunda e principal ressalva é o fato de uma cidade poder suspender o eterno retorno cíclico por meio de um regime que combine as três formas. Se o ciclo de degeneração decorre da instabilidade que as três formas de governo carregam em si, caso hajam indivíduos aptos a constatar esta instabilidade, é possível ordenar uma república que retarde a corrupção e suspenda o eterno retorno. "Para que a adesão do secretário florentino fosse completa, era preciso que ele declarasse explicitamente que aderia à idéia de um eterno retorno e, assim, que o modelo de Políbio servia também para compreender a política de seu tempo" (BIGNOTTO, 1991, p.176).

Ainda no que diz respeito à edificação da cidade e a importância de conhecer a história, caso a fundação seja livre (ou seja, caso a cidade não seja submetida a nenhuma outra), para que a liberdade se mantenha (e não 
ocorra o 2.2.2), o edificador deve ter virtủ, tanto na escolha do local ou quanto na ordenação das leis e das instituições políticas. Como já mencionado, há aquelas cidades que, mesmo tendo nascido livres, não são bem ordenadas de início, perfazendo os ciclos históricos ao se corromperem (2.2.2). Mas, se a cidade tiver uma fundação livre por um edificador virtuoso, devem haver instituições capazes de frear a corrupção por meio de um governo misto. Caso ainda a cidade, embora tenha nascido livre, não tenha sido ordenada de início por um fundador virtuoso, ela pode alcançar a ordenação perfeita pela força da contingência, dos conflitos.

\section{A ORDENAÇÃo CONFLITIVA DE ROMA: DOS TUMULTOS A PERFEIÇÃO INSTITUCIONAL}

Feita a exposição sobre o caráter cíclico do tempo, Maquiavel volta sua atenção para a ordenação de Roma que, não tendo sido bem ordenada por um legislador ou edificador virtuoso e sábio no momento da fundação, alcançou a perfeição institucional graças à contingência (2.2.3) e à virtude popular. Conforme mencionado, dentre as cidades que alcançam uma ordenação satisfatória para frear a degeneração política cíclica, há aquelas que receberam as leis e ordenação de uma só vez por um legislador virtuoso e aquelas que, não recebendo de uma só vez, tiveram de se ordenar por si mesmas, segundo acontecimentos marcados por conflitos e circunstâncias da fortuna, como foi o caso de Roma.

Embora Roma não tivesse um Licurgo que no princípio a ordenasse de tal modo que lhe permitisse viver livre por longo tempo, foram tantos os acontecimentos que nela surgiram, devido à desunião que havia entre a plebe e o senado, que aquilo que não fora feito por um ordenador foi feito pelo acaso. Porque, se Roma não teve a primeira fortuna, teve a segunda; pois se suas primeiras ordenações foram insuficientes, nem por isso a desviaram do bom caminho que a pudesse levar à perfeição. [...] permanecendo mista, constituiu-se uma república perfeita: perfeição a que se chegou devido à desunião entre plebe e senado [...] (MAQUIAVEL, 2007, p.18-19).

Os legisladores e ordenadores virtuosos são aqueles que, reconhecendo a instabilidade das formas isoladas de governo, instituem um Estado no qual coexistem as três. Numa cidade onde existe, ao mesmo tempo, um principado, aristocratas e um governo popular, cada uma destas partes deve tomar conta das demais. Neste sentido, só é possível pensar um modelo político estável se nele coexistirem as três formas de governo. Assim, pode-se inferir que para que as cidades nascidas livres que não foram ordenadas de plano por um edificador virtuoso possam chegar à perfeição institucional, como Roma, deve haver uma saudável desunião conflitiva entre os humores. O que ocorreu em Roma foi que os grandes, em busca de poder, tentaram subjugar a plebe, mas encontraram forte resistência. Quando ficou insustentável a manutenção da submissão política da plebe, os grandi tiveram de viabilizar leis e instituições republicanas, momento em que foram criados os tribunos (ADVERSE, 2007). 
Como expõe Maquiavel, Roma foi fundada como uma monarquia por Rômulo e os primeiros reis e, após a expulsão dos Tarquínios, foi estabelecido uma aristocracia. Todavia, assim como é a tendência de todo sistema de governo isolado, tal governo se corrompeu e só devido a uma série de acidentes resultantes dos conflitos oriundos da desunião entre a plebe e o senado Roma se ordenou como república. Necessário ressaltar que Roma só alcançou a perfeição porque o senado (que representava a nobreza) cedeu às pressões da plebe. Para ilustrar, Maquiavel apresenta "[...] como, juntos, a plebe e o Senado expeliram os reis e como, quando o Senado começou a abusar da plebe, o povo instituiu os tribunos para agirem em seu interesse" (MCCORMICK, 2013, p.259). Se isso não tivesse ocorrido, Roma teria se tornado um governo popular e, após, uma licença.

Assim, Roma, tendo nascido como um principado "puro", se corrompeu e, tão logo os reis Tarquínios foram depostos após a degeneração do principado inicial, pairou uma aparência de união entre plebe e senado, "[...] e parecia que os nobres haviam renunciado à soberba, que tinham disposições mais populares e podiam ser suportados por todos, mesmo os de ínfima condição" (MAQUIAVEL, 2007, p.20). Enquanto os Tarquínios estavam vivos, a aparente união persistiu. Os nobres receavam que se a plebe fosse maltratada, ela se reaproximasse dos reis depostos. Todavia, quando estes morreram, o senado perdeu o medo da plebe, passando a desrespeitá-la.

Porém, após um enorme abuso dos nobres, o povo deixa Roma massivamente. Os nobres, temendo pela defesa da cidade, chamaram a plebe de volta e estabelecem o tribunato. Os escritos de Lívio acerca da criação dos tribunato (instituição que efetivava a participação plebeia e viabilizava o controle sobre os grandi) demonstram claramente os fatos narrados por Maquiavel sobre os eventos que levaram Roma à perfeição institucional (MCCORMICK, 2013, p.259-260). Após “[...] muitas confusões, tumultos e perigos de perturbações, surgidos entre a plebe e a nobreza, chegou-se à criação dos tribunos, para a segurança da plebe" (MAQUIAVEL, 2007, p.21). O tribunato era a instituição de mediação entre povo e senado, tendo uma função mais reativa e preventiva que construtiva ou propositiva (MCCORMICK, 2013). Conforme Menezes (2012, p.29), embora o tribunato fosse uma magistratura dotada de imunidade quanto à eventuais responsabilizações civis e penais durante o exercício do mandato, não tinha o poder de imperium como outras magistraturas, ou seja, os tribunos não podiam executar ordens, somente vetá-las.

Vale esclarecer que eram facultados aos tribunos da plebe - ou ao menos lhes seriam facultados até a República tardia - os seguintes poderes: proteger um plebeu de decisões de outros magistrados (ius auxilii); conclamar e dirigir o concilium plebis no exercício de todas as atribuições legais deste; convocar e discursar em contiones; convocar o Senado; obnuntiatio; e, finalmente, o poder de vetar qualquer ação de qualquer magistrado e do Senado (intercessio) (MENEZES, 2012).

Assim, os tumultos e desordens bem como o medo dos grandi fizeram com que Roma chegasse à boa ordenação, o que se deveu à boa virtù da plebe. Com isso, o ciclo histórico-político de degeneração foi suspenso, 
passando a coexistir na república: o poder principesco, corporificado na figura dos cônsules; uma instituição na qual a ânsia opressiva dos nobres podia tomar corpo, embora jamais fosse saciada, que era o senado; uma magistratura que dava à plebe a possibilidade de refrear a opressão dos nobres e de ser ouvida, que era o tribunato. Além disso, foram estabelecidas medidas institucionais, como a colegialidade das magistraturas e a acusação pública, para que os ânimos dos humores pudessem se desafogar.

Neste sentido, "[...] Maquiavel identifica a maturação da república romana com o estabelecimento de suas três partes principais: um poder principesco domado nos cônsules, um poder aristocrático em certa medida disciplinado no Senado, e um poder popular virtuoso nos tribunos" (MCCORMICK, 2013, p.261). Os cônsules

[...] eram eleitos anualmente por assembleias dominadas pelos nobres e, inicialmente, tinham que ser membros da nobreza. Os cônsules eram magistrados executivos encarregados de deveres administrativos e militares e podiam ser influenciados tanto pelos nobres como pelo povo. A possibilidade de influência sobre os cônsules aumentou quando foi suspensa a proibição do casamento entre classes (445 a.C.) e quando finalmente se permitiu que plebeus servissem como cônsules (300 a.C.) (MCCORMICK, 2013, p.261262).

O senado, como já mencionado, tinha um papel de expressão quase direta da nobreza. Ainda que tivesse, formalmente, uma função meramente consultiva, na prática exercia uma enorme influência em todos os assuntos públicos, a começar pela eleição dos cônsules. O tribunato, instituição à qual Maquiavel dedica grande atenção, refletia as preferências populares, mesmo que nem sempre de forma direta. $\mathrm{O}$ florentino ressalta que embora os tribunos procurassem agir no interesse das massas, algumas vezes eles contrariavam os desejos imediatos do povo. Todavia, a função mais importante dos tribunos era a de manter responsável a elite, uma vez que eles podiam vetar ou sancionar propostas de ações dos cônsules e do senado (MCCORMICK, 2013, p.262).

Importante frisar que tanto os cônsules quanto os tribunos, assim como a maioria das magistraturas, eram eleitos para mandatos de um ano, vedada reeleição. Só se poderia concorrer novamente ao cargo ocupado dez anos após o término do mandato. Nesse sentido, McCormick ressalta que o incentivo para que as magistraturas fossem receptivas com o povo era a possibilidade de acusação pública e a subsequente punição das autoridades, e não propriamente a vontade de ser reconduzido no ofício. "Por meio do poder de coertio, os tribunos poderiam tentar punir os cônsules por sua conduta no cargo uma vez terminado seu mandato, mas essa era apenas uma punição ex post' (MCCORMICK, 2013, p.263). “Todas essas são proteções ou recursos contra a ação agressiva ou à usurpação por parte da nobreza ou dos magistrados" (MCCORMICK, 2013, p.260).

Por todas essas conquistas decorrentes dos tumultos populares, Maquiavel conclui que os conflitos ocorridos em Roma foram decisivos para o aperfeiçoamento das instituições republicanas, uma vez que levaram à ordenação institucional da liberdade ao viabilizar ao povo meios de participação e medidas para refrear o humor opressor da nobreza. Assim, ele contraria a tradição ao dizer que a grandeza de Roma se deve ao seu caráter 
tumultuário. Foi a própria (des)ordem de Roma que tornou possível a instituição e a guarda da liberdade na república. O florentino narra, aprovativamente, o modo como o povo protestou contra o senado, evacuou a cidade e promoveu desordens.

Entretanto, cabe esclarecer que embora os conflitos tenham trazido resultados positivos à cidade de Roma, Maquiavel não promove um elogio irrestrito dos tumultos. Isso porque em Roma as dissenções levaram a uma ordenação perfeita, Florença se mostra como um caso particular. O florentino, no primeiro capítulo do Livro III da História de Florença, sintetiza de forma bastante elucidativa as diferenças entre os conflitos em Florença e em Roma:

As graves inimizades que há entre os homens do povo e os nobres, causadas pela vontade que estes têm de comandar e aqueles de não obedecer, são a razão de todos os males das cidades; porque dessa diversidade de humores alimentam-se todas as outras coisas que perturbam as repúblicas. Foi o que manteve Roma desunida; é também - se for lícito comparar coisas pequenas e coisas grandes - o que manteve Florença dividida; se bem que os efeitos gerados em cada uma das cidades foram diferentes: porque as inimizades havidas em Roma, em princípio, entre o povo e os nobres eram definidas por disputas, enquanto as de Florença o eram por combates; as de Roma terminavam com leis, enquanto as de Florença terminavam com o exílio e com a morte de muitos cidadãos; as de Roma sempre aumentavam a virtù militar, enquanto as de Florença a extinguiam totalmente; em Roma, a igualdade entre os cidadãos levou a grandíssima desigualdade, enquanto em Florença, de desigualdade, chegou-se a uma admirável igualdade. Tal diversidade de efeitos só pode ser causada pelos diferentes fins que os dois povos tinham em mira: porque o povo de Roma desejava gozar as supremas honras ao lado dos nobres, enquanto o de Florença combatia para ficar sozinho no governo, sem a participação dos nobres. E, como o desejo do povo romano era mais razoável, as ofensas aos nobres acabavam por ser mais suportáveis, de tal modo que aquela nobreza cedia facilmente e sem recorrer às armas; assim, depois de algumas desavenças, concordavam em criar uma lei que satisfizesse ao povo e aos nobres em seus cargos. Por outro lado, o desejo do povo florentino era injurioso e injusto, de tal modo que a nobreza preparava sua defesa com maiores forças, e, por isso, chegava-se ao derramamento de sangue e ao exílio dos cidadãos, e as leis depois criadas não miravam à utilidade comum, mas eram ordenadas todas a favor do vencedor (MAQUIAVEL, 2007, p.157-158)

Esse trecho deixa claro um dos principais motivos pelos quais o conflito em Florença era reprovável. Além disso, Maquiavel também expõe, no capítulo 34 do Livro II da História, que, embora muitas repúblicas tenham tido divisões claras, grande parte destas repúblicas consolidou apenas uma divisão que ora ampliou a cidade, ora a arruinou. Em Florença, todavia, originaram-se inúmeras divisões (não apenas a clássica divisão romana entre plebe e nobreza), as quais progressivamente a arruinaram: primeiramente, os nobres se dividiram entre si; em seguida, houve uma divisão entre os nobres e o povo; por fim, surge uma divisão entre o povo e a plebe. Por vezes, uma dessas partes, tendo vencido um confronto e se sobreposto à outra (de modo a anulá-la), se dividia em duas. Além disso, sempre que um confronto ocorria entre as referidas divisões, ao final dele, havia inúmeras mortes, exílios e destruições de famílias.

Os conflitos em Florença são complexos na medida em que as oposições fundamentais entre os 
humores se tornaram fluídas, artificiais e não naturais. Os grupos que passam a se confrontar não o fazem quando se trata de discórdias naturais e inevitáveis (distinguindo-se no modo de desejar), pois as divisões se dão dentro de um mesmo humor e são, por conseguinte, artificiais. Isso evidencia o motivo pelo qual Maquiavel relança sua análise dos conflitos criticando seus efeitos em Florença. “[...] em Roma, era o fundamento da liberdade e grandeza da república e, portanto, positivo; em Florença, nutre a contínua crise, 'origem de tantas mortes, tantos exílios, tantas destruições de famílias' ('História de Florença', Proêmio) e, portanto, negativo" (AMES, 2014, p.268).

Devido a essa abordagem distinta com relação ao tema do conflito, alguns intérpretes do pensamento maquiaveliano ressaltam uma suposta ruptura acerca do conflito dos Discursos sobre a primeira década de Tito Lívio para a História de Florença. Os Discursos seriam elogiosos para com os tumultos promovidos pela plebe e a forma como o humor do povo foi decisivo para a instituição e manutenção da liberdade em Roma, tendo tido um papel determinante no alcance da perfeita ordenação dessa república. Já na História de Florença, Maquiavel teria adotado um tom recriminador em relação ao povo florentino por ter protestado contra a opressão da elite por meio de uma insurreição, assumindo um tom mais elogioso em relação ao humor dos grandi.

\section{AS POTENCIALIDADES DO CONFLITO}

Maquiavel, por mais que não examine os eventos históricos visando à verdade histórica, parte de exemplos paradigmáticos e, com isso, suscita questões políticas importantes sobre a cidade. Ao analisar os conflitos que levaram Roma à perfeição política, o florentino remete esse problema a questões mais profundas, que dizem respeito à essência das comunidades políticas. Para Gaille-Nikodimov (2004, p.13), é como se Maquiavel tivesse tido contato com a expressão "sociedade dinâmica" (société chaude) de Lévi-Strauss, segundo a qual existem, em todas as sociedades, diferenciações fundamentais entre castas sociais que se manifestam sem cessar.

Com isso, muitos intérpretes do pensamento maquiaveliano ressaltam seu caráter de ruptura em relação a uma tradição que valoriza e, até mesmo, absolutiza o consenso e a harmonia como categorias políticas (a denominada tradição dos pensadores da harmonia política). Quando Maquiavel pensa o conflito como propulsor da vida política, assim como o caráter necessário das diferenciações, ele se destaca da tradição que o precedeu. Nesse sentido, ao questionar o consenso e a harmonia social como categorias políticas boas em si mesmas, Maquiavel coloca o conflito como um elemento primordial da vida institucional de uma cidade. Todavia, inferir disso que ele promove um elogio irrestrito do conflito cívico é um equívoco (GAILLE-NIKODIMOV, 2004; 
MCCORMICK, 2011; AMES, 2014) 5 .

O conflito emerge de uma oposição fundamental entre os dois humores, o dos grandes e o da plebe, e é um tema tratado por Maquiavel em suas principais obras: O príncipe, Discursos sobre a primeira década de Tito Lívio e História de Florença. Se, na primeira obra, essa temática é tratada a partir das reflexões sobre o principado civil no Capítulo IX, nos demais escritos, Maquiavel coloca a questão dos enfrentamentos entre os humores no centro de suas análises, embora aborde o tema em momentos históricos diferentes em cada uma delas. Nos Discursos são analisados eventos da história da Roma antiga. Na História são problematizados acontecimentos de Florença. Além disso, nos Discursos, o florentino desenvolve uma argumentação que ressalta as potencialidades positivas dos conflitos, ao passo que, na História, ele retrata seu potencial nocivo à comunidade política.

Devido a isso, surgiram interpretações que sustentam haver uma reorientação teórica sobre a questão do conflito de um escrito (Discursos) para o outro (História). Os Discursos seriam elogiosos para com os tumultos promovidos pela plebe e a forma como o humor do povo foi decisivo para a instituição e manutenção da liberdade em Roma, tendo tido um papel determinante no alcance da perfeita ordenação dessa república. Já na História de Florença, Maquiavel teria adotado um tom recriminador em relação ao povo florentino por ter protestado contra a opressão da elite por meio de uma insurreição, assumindo um tom mais elogioso em relação ao humor dos grandi. Por essas razões, alguns estudiosos sustentam a História teria sido escrita a partir de uma reorientação de pensamento de Maquiavel.

Por isso, alguns estudiosos irão posicionar as reflexões da História de Florença (recriminação das desordens e das insurreições contra as opressões dos nobres e o tom elogioso em relação ao humor dos grandes) como sendo uma tentativa de Maquiavel de agradar seus leitores mais imediatos, hipótese defendida por McCormick, em Machiavelli, Popular Resistance and the Curious Case of the Ciompi Revolt, e por Skinner, em

\footnotetext{
${ }^{5}$ Segundo Ames (2009, p.182-183), analisar o pensamento de Maquiavel como uma ruptura no que diz respeito à questão do conflito induz a pensar que haveria "[...] de um lado, uma ideia de concórdia comum a toda tradição, e, de outro, que encontraríamos uma negação radical dela em Maquiavel. Como bem mostrou M. Senellart (1996), nem uma nem outra se sustentam. Não existe na ideia de concórdia um núcleo estável de significação. Antes, diz o comentador, trata-se de "um termo multiforme, no qual se cruzam, se sobrepõem ou se confrontam lógicas argumentativas muito diferentes. Ele designa um espaço teórico no seio do qual coexistem numerosos arranjos possíveis". Apoiando esta conclusão, Senellart identifica cinco concepções filosóficas distintas de concórdia desenvolvidas ao longo da história: eunômica, harmônica, agonística, eudemônica e irênica. Reconhece Maquiavel próximo da agonística, de origem heraclitiana (harmonia como tensão entre contrários), mas não exclui a influência das posições eunômica, de origem socrática (concórdia como obediência às leis) e harmônica, que remonta a Pitágoras, mas tem em Cícero a fonte mais próxima (harmonia do universo como modelo do Estado bem ordenado). É, pois, pouco plausível a afirmação de que Maquiavel romperia de modo radical e definitivo com toda uma tradição que valoriza a concórdia civil. Isso porque semelhante tradição, rigorosamente falando, não existe, pois há diversas - e diferentes entre si — concepções de concórdia, como também porque é improvável que ele se oponha sistematicamente a esse ideal a ponto de dispensar toda necessidade de acordo. Muito embora Maquiavel faça nascer dúvidas sobre a concórdia como ligação necessária da política, nem por isso faz um elogio sem limites ao conflito civil [...]. Em outras palavras, e generalizando as posições sintetizadas por Senellart: enquanto uns veem na posição de Maquiavel uma ruptura com a tradição, outros colocam o florentino na linha de continuidade do
} 
Maquiavel. Isso porque a referida obra de Maquiavel foi escrita mediante encomenda formal dos Medici.

Logo depois de concluir os Discursos, uma súbita mudança na roda da Fortuna finalmente trouxe a Maquiavel o patronato do governo dos Medici, a que sempre aspirara. Lorenzo de Medici - a quem ele havia dedicado O príncipe, após a morte de Giuliano em 1516 morreu em idade prematura três anos depois. O sucessor no controle dos assuntos florentinos foi seu primo, o cardeal Giulio, que logo seria eleito papa Clemente VII. Acontece que o cardeal era parente de um dos amigos mais próximos de Maquiavel, Lorenzo Strozzi, a quem ele dedicou mais tarde $A$ arte da guerra. Devido a essa ligação, Maquiavel conseguiu ser apresentado à corte dos Medici em março de 1520, e logo depois recebeu a insinuação de que poderiam lhe encontrar uma ocupação - se não diplomática, ao menos literária. Ele não foi frustrado em suas expectativas, pois em novembro do mesmo ano recebeu uma encomenda formal dos Medici para escrever a história de Florença (SKINNER, 2012, p.106).

Todavia, essa suposição incorre em um salto interpretativo arriscado. O que se pode depreender de uma análise depurada das obras é que as supostas rupturas no exame dos conflitos não decorreriam nem de um deslocamento conceitual nem de um "objetivo oculto" de aprazer seus leitores imediatos, mas do fato de que em um escrito (Discursos sobre a primeira década de Tito Lívio) Maquiavel analisa os efeitos positivos dos conflitos, ao passo que no outro (História de Florença) ele analisa seus efeitos nocivos em uma comunidade política. Neste sentido, o florentino não sustenta que os conflitos são um bem "em si mesmos", mas que eles, sendo uma categoria ontológica da política, podem gerar tanto efeitos positivos ou negativos no âmbito institucional (assim como a busca pela harmonia).

Em Roma, por exemplo, os conflitos entre a plebe e o senado geraram efeitos positivos, uma vez que foram instituídos os tribunos e outras formas de os humores poderem desafogar seus ânimos pela via institucional, como a acusação pública. Todavia, disso não se pode depreender que conflito, liberdade e ordenação perfeita sejam sinônimos, embora sejam noções imbricadas na constituição de uma república bem ordenada como a romana. Há conflitos que geram efeitos positivos e conflitos que geram efeitos negativos. Quando os conflitos geram efeitos positivos, as instituições ou os atores políticos, ao final de um momento de tensão, são capazes de traduzir os enfrentamentos em boas leis e ordenações ${ }^{6}$. Quando os conflitos geram efeitos negativos, a cidade é enfraquecida e, com isso, a diferenciação entre os humores, a liberdade e a ordem republicana são ameaçadas.

Tanto não há que se falar numa ruptura conceitual em relação ao tema dos conflitos entre os Discursose a História que o próprio Maquiavel, nos Discursos, capítulo 8, Livro I, compara a diferença dos efeitos dos

pensamento republicano clássico". Todavia, para o propósito deste trabalho, problematizar estas questões seria um exercício interpretativo desnecessário, que se distanciaria sobremaneira do tema proposto.

${ }^{6}$ Evidentemente, o bem ordenar de uma cidade não é alcançar um estado de plena harmonia no qual os conflitos desapareçam, mas justamente o oposto: as boas ordenações farão com que, desde a fundação da cidade, não seja necessário o recurso às vias extraordinárias para que a cidade alcance a participação ampla (uma vez que o conflito "extraordinário" tanto pode ocasionar instituições livres quanto o agravamento da situação da cidade). Assim, diante da possibilidade de que certos conflitos (que, como foi o caso de Roma antes da instituição dos tribunos, ocorreram pela via extraordinária) possam ocasionar guerras civis, vinganças 
conflitos em Roma e em Florença ao discorrer sobre a importância da ordenação das acusações públicas:

[...] como se disse, era bem-ordenada em Roma; e foi sempre mal ordenada na nossa cidade de Florença. E, assim como em Roma essa ordenação fez muito bem, em Florença essa desordem fez muito mal. E quem lê as histórias desta cidade verá quantas calúnias foram lançadas em todos os tempos contra seus cidadãos que trabalharam nas coisas importantes da cidade. De um diziam que havia roubado o dinheiro público; de outro, que não vencera uma empresa por ter sido corrompido; e que aqueloutro, por ambição, cometera este ou aquele inconveniente. Motivo por que de todos os lados surgia o ódio: deste se chegava à divisão, e da divisão às facções; das facções à ruína. Porque, se em Florença tivesse havido uma ordenação que possibilitasse a acusação dos cidadãos e punisse os caluniadores, não teriam ocorrido os infinitos tumultos que ocorreram (MAQUIAVEL, 2007, p.39).

Nesse sentido, é a tese sustentada por Gaille-Nikodimov (2004), segundo a qual o tema dos conflitos civis em Maquiavel não sofre mutações no decorrer da obra, mas é, sobretudo, tratado com "notável coerência" em todo seu trabalho. As supostas diferenças nas análises maquiavelianas sobre o tema dos conflitos se dariam não por uma guinada em seu pensamento, mas por uma diferença nos efeitos em potencial que os conflitos civis podem gerar.

Portanto, sendo o político, para Maquiavel, definido pelo conflito, não parece equivocado sustentar a hipótese de que sua obra não é marcada por uma ruptura conceitual. Na verdade, o que se pode dizer é que os conflitos podem gerar efeitos distintos no âmbito de comunidades distintas. Neste sentido, os conflitos podem ocasionar os seguintes efeitos: 1) os humores, ao não encontrarem vazão e regulação institucional, se sobrepõem um ao outro e, com isso, fazem a cidade percorrer o ciclo polibiano; 2) os humores podem encontrar uma oposição equilibrada, fazendo com que a liberdade se consolide nas instituições, como se deu em Roma; 3) os conflitos entre os humores, mesmo que ocorram de forma perene, não encontram vazão institucional, gerando efeitos negativos para a cidade e fazendo com que ela oscile entre licença e tirania (AMES, 2009, p.186). Este é justamente o ponto diferenciador dos desdobramentos dos conflitos em Roma e em Florença ${ }^{7}$. Roma percorreu parte do ciclo polibiano, mas retificou seu caminho estabelecendo um regime misto. Assim, foi sentida em Roma parte dos efeitos negativos do "1)", mas, por força de acidentes, os romanos foram capazes de consolidar boas

privadas, instabilidades, divisões sociais artificiais e, com isso, a fraqueza da cidade, o papel das boas leis e ordenações é viabilizar uma "vazão institucional" ao conflito a fim de que dele advenham instituições boas e equilíbrio.

${ }^{7}$ Ames, embora sugira que há uma redefinição da noção de conflito em Maquiavel, demonstra que há continuidade conceitual. Ele aponta para o fato de que "Roma e Florença viveram as dissensões de modo diferente: enquanto a história de Roma pode ser caracterizada como passagem da potência ao declínio e crise a partir de um modelo de conflito dual (positivo/negativo), a história de Florença é crise do começo ao fim, e a potência não aparece como polo oposto à crise (como em Roma), do mesmo modo que o conceito foge ao esquematismo dual. O conceito se desdobra, progressivamente, em múltiplas formas impossíveis de serem reduzidas ao esquema positivo/negativo" (AMES, 2014, p.267). A argumentação que Ames desenvolve em "Transformações do significado de conflito na 'História de Florençà de Maquiavel” corrobora tal sugestão, pois, para ele, a principal diferença na tratativa do tema do conflito entre Roma e Florença seria que, na cidade florentina, sempre que um grupo alcançava a vitória, ele encontrava um novo motivo para se dividir e renovar um conflito por vias extraordinárias, ao invés de tentar instituir ordenações e leis para que houvesse uma saída "livre" do conflito. Assim, se nos Discursos o pensador florentino explicita a importância de haver uma estrutura institucional que viabilize mecanismos ordinários para dar vazão ao conflito, em Florença os enfrentamentos não tiveram os mesmos efeitos. 
instituições, de modo que os conflitos puderam ocasionar bons efeitos, conforme o "2)". Florença, por outro lado, teve sua história marcada pelo terceiro efeito potencial dos conflitos.

Maquiavel, logo no primeiro capítulo do Livro III da História de Florença, sintetiza novamente de forma bastante elucidativa as diferenças entre os efeitos dos conflitos em Florença e em Roma:

As graves inimizades que há entre os homens do povo e os nobres, causadas pela vontade que estes têm de comandar e aqueles de não obedecer, são a razão de todos os males das cidades; porque dessa diversidade de humores alimentam-se todas as outras coisas que perturbam as repúblicas. Foi o que manteve Roma desunida; é também - se for lícito comparar coisas pequenas e coisas grandes - o que manteve Florença dividida; se bem que os efeitos gerados em cada uma das cidades foram diferentes: porque as inimizades havidas em Roma, em princípio, entre o povo e os nobres eram definidas por disputas, enquanto as de Florença o eram por combates; as de Roma terminavam com leis, enquanto as de Florença terminavam com o exílio e com a morte de muitos cidadãos; as de Roma sempre aumentavam a virtù militar, enquanto as de Florença a extinguiam totalmente; em Roma, a igualdade entre os cidadãos levou a grandíssima desigualdade, enquanto em Florença, de desigualdade, chegou-se a uma admirável igualdade. Tal diversidade de efeitos só pode ser causada pelos diferentes fins que os dois povos tinham em mira: porque o povo de Roma desejava gozar as supremas honras ao lado dos nobres, enquanto o de Florença combatia para ficar sozinho no governo, sem a participação dos nobres. E, como o desejo do povo romano era mais razoável, as ofensas aos nobres acabavam por ser mais suportáveis, de tal modo que aquela nobreza cedia facilmente e sem recorrer às armas; assim, depois de algumas desavenças, concordavam em criar uma lei que satisfizesse ao povo e aos nobres em seus cargos. Por outro lado, o desejo do povo florentino era injurioso e injusto, de tal modo que a nobreza preparava sua defesa com maiores forças, e, por isso, chegava-se ao derramamento de sangue e ao exílio dos cidadãos, e as leis depois criadas não miravam à utilidade comum, mas eram ordenadas todas a favor do vencedor (MAQUIAVEL, 2007, p.157-158)

Esse trecho deixa claro um dos principais motivos pelos quais o conflito em Florença era reprovável. Além disso, Maquiavel também expõe, no capítulo 34 do Livro II da História, que, embora muitas repúblicas tenham tido divisões claras, grande parte destas repúblicas consolidou apenas uma divisão que ora ampliou a cidade, ora a arruinou. Em Florença, todavia, originaram-se inúmeras divisões (não apenas a clássica divisão romana entre plebe e nobreza), as quais progressivamente a arruinaram: primeiramente, os nobres se dividiram entre si; em seguida, houve uma divisão entre os nobres e o povo; por fim, surge uma divisão entre o povo e a plebe. Por vezes, uma dessas partes, tendo vencido um confronto e se sobreposto à outra (de modo a anulá-la), se dividia em duas. Além disso, sempre que um confronto ocorria entre as referidas divisões, ao final dele, havia inúmeras mortes, exílios e destruições de famílias.

Os conflitos em Florença são complexos na medida em que as oposições fundamentais entre os humores se tornaram fluídas, artificiais e não naturais. Os grupos que passam a se confrontar não o fazem quando se trata de discórdias naturais e inevitáveis (distinguindo-se no modo de desejar), pois as divisões se dão dentro de um mesmo humor e são, por conseguinte, artificiais. Isso evidencia o motivo pelo qual Maquiavel relança sua análise dos conflitos criticando seus efeitos em Florença. “[...] em Roma, era o fundamento da liberdade e grandeza 
da república e, portanto, positivo; em Florença, nutre a contínua crise, 'origem de tantas mortes, tantos exílios, tantas destruições de famílias' ('História de Florença', Proêmio) e, portanto, negativo” (AMES, 2014, p.268).

\section{CONSIDERAÇÕES FINAIS}

A partir do que foi desenvolvido, é possível extrair algumas marcas do pensamento de Maquiavel. Primeiramente, (1) uma rejeição à ideia de que uma comunidade política seja una, na medida em que haveria interesses políticos ontologicamente antagônicos que atuariam visando a anulação um do outro. Além disso, (2) instituições políticas que reconheçam a existência das divisões sociais e operem de modo a inviabilizar que um dos "humores" anule os demais são cruciais para a manutenção da "saúde" da polis. Ainda, (3), embora o antagonismo conflitivo seja uma marca de toda e qualquer comunidade política, a aptidão de uma cidade em suspender o eterno retorno depende de sua habilidade em fazer com que os humores se relacionem de modo que um não anule o outro.

O pensamento maquiaveliano assinala algo que passa a fazer parte da política moderna: que uma comunidade política é um corpo plural - embora a forma como essa ideia será institucionalizada leve a fortes desigualdades. Com isso, são criadas instituições que têm como escopo a tentativa de conciliar os interesses heterogêneos dos cidadãos dentro da polis. A dificuldade desse projeto está justamente no fato de que esses interesses, que podem ser identificados por grupos, acabam entrando em conflitos uns com os outros. Isso porque, segundo Maquiavel (conforme será evidenciado), os desejos humanos (tanto numa dimensão individual quanto na dimensão coletiva dos humores dos grandes e do povo) tendem à desmesura (e esse é um elemento que é desconsiderado pelas instituições representativas modernas).

Devido a isso, a luta entre os humores obriga os atores políticos a rever permanentemente a ordem institucional. Maquiavel recusa a ideia de que existam leis aptas a refrear e regular de uma vez por todas o conflito. Tanto os humores quanto os motivos que acarretam os conflitos se alteram, assim como a forma como os conflitos são levados (ou não) à via institucional. Assim, o caráter dinâmico e desmedido dos desejos humanos antagônicos leva ao desafio de pensar constantemente (eternamente) a política como tendo sua fonte no conflito, uma dimensão que tem por desafio inscrever a desordem (caos) na ordem. Assim, a suspensão do eterno retorno depende de uma série de fatores, sendo o principal deles a boa tradução institucional dos conflitos que ocorrem no corpo político. 


\title{
ETERNAL RETURN AND THE INSTITUTIONAL PERFECTION IN MACHIAVELLI
}

\begin{abstract}
The scope of the text is to analyze the political eternal return and the possibility of avoiding it by a republican institutional arrangement in Machiavelli. In this sense, this work, carried out through a bibliographical analysis of the Machiavellian works, is located in the field of Political Philosophy, especially when it assumes that its central problem is the question of the best regime. To Machiavelli, human history, which is political (since the human being is a political being), is cyclical and marked by a natural degeneration of the pure forms of government (principality, aristocracy, democracy), which leads to the eternal return. However, the cyclical character of the political is relative since a well-ordered city may suspend political-institutional degeneracy, like Rome. That is, the political result achieved by the Roman republic must be understood as paradigmatic.
\end{abstract}

Keywords: institutional perfection; eternal return; forms of government; republic.

\section{REFERÊNCIAS BIBLIOGRÁFICAS}

ADVERSE, Helton. "Maquiavel, A República e o Desejo de Liberdade". In: Trans/Form/Ação, v. 30, p.33-52, 2007. Disponível em: http://www.scielo.br/pdf/trans/v30n2/a04v30n2.pdf. Acesso em 15 de novembro de 2013.

"Matriz italiana”. In. BIGNOTTO, Newton (org.). Matrizes do republicanismo. Belo Horizonte: Editora UFMG, 2013.

AMES, José L.. "História e Ação Política em Maquiavel”. In: Mediações Revista de Ciências Sociais, vol. 9, n. 1, 2014, p.101-118.

"Lei e violência ou a legitimação política em Maquiavel". In: Trans/Form/Ação, Marília, v.34, n.1, 2011, p.21-42.

"Liberdade e conflito - O confronto dos desejos como fundamento da ideia de liberdade em Maquiavel". In: Kriterion, Belo Horizonte, n. 119, 2009, p.179-196.

"Maquiavel e a educação: a formação do bom cidadão". In: Trans/Form/Ação, São Paulo, n 31, vol. 2 , 
2008, p.137-152

"Transformações do significado de conflito na História de Florença de Maquiavel". In: Kriterion, Belo Horizonte, n 129, 2014, p.265-286.

BIGNOTTO, Newton. Maquiavel Republicano. São Paulo: Edições Loyola, 1991. (org.). Matrizes do republicanismo. Belo Horizonte: Editora UFMG, 2013. "Maquiavel historiador". In: Revista USP, São Paulo, n 29, 1996, p.182-188.

BRANCO, Guilherme Castelo e ADVERSE, Helton Machado (orgs.). Clássicos e contemporâneos da filosofia política: de Maquiavel a Antonio Negri. Belo Horizonte: Relicário, 2015.

GAILLE-NIKODIMOV, Marie. Conflit civil et liberté. La politique machievélienne entre histoire et médecine. Paris: Honoré Champion, 2004.

MAQUIAVEL, Nicolau. Discursos sobre a primeira década de Tito Lívio. Glossário e revisão técnica de Patrícia Fontura Aranovich. Trad. MF. São Paulo: Martins Fontes, 2007a.

História de Florença. Glossário e revisão técnica de Patrícia Fontura Aranovich. Trad. MF. São Paulo: Martins Fontes, 2007b. Opríncipe. Trad. Maria Júlia Goldwasser. 2 ed. São Paulo: Martins Fontes, 2001.

MARIN, Marcelo P.. Maquiavel e Guicciardini: liberdade cívica e discórdias civis. Dissertação de mestrado apresentada ao Programa de Pós-graduação em Filosofia da Pontifícia Universidade Católica de São Paulo, 2007.

MCCORMICK, John. "Democracia maquiaveliana: controlando as elites com um populismo feroz". Trad. André Villalobos. In: Revista Brasileira de Ciência Política, n 12, Brasília, 2013, p.253-298.

MENEZES, Priscilla M. D. C. A. A origem e a evolução do tribunato da plebe na Roma republicana. Monografia apresentada ao Departamento de Direito da PUC-Rio, 2012.

MORAIS, Ricardo Manoel de Oliveira. "O Conflito e a História na teoria republicana: contraponto entre Guicciardini e Maquiavel”. In: Temporalidades Revista de História, v.6, n.1, 2014. Disponível em http://www.fafich.ufmg.br/temporalidades/pdfs/12p100.pdf. Acesso de 30 de novembro de 2016. 
VALVERDE, Antonio J. R. "A liberdade cívica no Livro I dos Discorsi de Maquiavel”. In: Hypnoe, ano 4, n 5 , 1999, p.337-354. Disponível em http://www.hypnos.org.br/revista/index.php/hypnos/article/view/343/347. Acesso em 12 de outubro de 2016.

Trabalho enviado em 02 de janeiro de 2018 Aceito em 14 de março de 2018 